\title{
MORE UNITED STATES TREE SWALLOW RECOVERIES
}

DONALD J. STILES, 20 Lake Wapta Rise SE, Calgary, AB T2J 2M9, and MARY I. HOUSTON, 863 University Drive, Saskatoon, SK S7N 0J8

Here we report five recent Tree Swallow band encounters. Two swallows had flights between the Alberta foothills and California. A third flew east and was mist-netted in Michigan. We also report the second occasion in which two Tree Swallows, banded in different places on the Canadian prairies, were recovered at the same location in southern Louisiana (the first such occasion ${ }^{2}$ is reproduced as numbers 1 and 2 in Table 1 and Figure 1).

Our previous reports of Tree Swallows banded in Alberta and Saskatchewan showed that this species follows a southeasterly route, with the most distant recoveries reaching South Carolina, Georgia, Mississippi and Louisiana. While a few may stay along the southern Atlantic and Gulf coasts for the winter, most are believed to migrate farther south, to Central America and Cuba during December, January and February, returning to the southern United States by March. ${ }^{5}$

\section{California}

Ray Harris caught an adult female Tree Swallow in one of his bluebird houses in the Porcupine Hills north of Pincher Creek, Alberta, on July 7, 1999. It had been banded $1050 \mathrm{~km}$ distant at the Modoc National Wildlife Refuge (NWR) near Alturas in northeastern California, on May 3, 1998. ${ }^{1}$ Traveling the opposite direction, a nestling banded by George Loades on his Jumping Pound trail southwest of Cochrane, $\mathrm{AB}$, on July 8, 1995, was mist-netted $1175 \mathrm{~km}$ distant at Modoc NWR on April 12, 1997. ${ }^{4}$

The Modoc NWR banding was part of the MAPS (Monitoring Avian Productivity and Survivorship) project, opening mist nets at set time intervals. Since most of the Modoc Tree Swallows raise their young in nestboxes at the site, the presence of migrant swallows coming from and going to southern Alberta was a surprise.

\section{Michigan}

A nestling banded near Dundurn, SK, on July 2, 2000 (MIH), was mist-netted 1660 $\mathrm{km}$ east-southeast at Vermilion Station, MI, by T. Allen of the Department of Biology at Superior University, on June 17, 2002.

The Vermilion Station is just west of the Whitefish Point banding station, which captures birds, including many raptors, as they cross a narrow part of Lake Superior, west of Sault Ste Marie. The only previous record of a Tree Swallow traveling mainly eastwards was a nestling from the Edmonton area recaptured four years later nesting in Wisconsin. ${ }^{2}$

\section{Louisiana}

Two nestling Tree Swallows were banded four years apart at the same latitude on bluebird trails: one near Olds, AB, on July 4, 1997 (DJS), and one near Pike Lake, SK, on June 25, 2001 (MIH). Both were found dead near Lake Charles, LA, on March 10, 2002, at a distance of 2960 and $2650 \mathrm{~km}$, respectively. John Robinette, a Louisiana Department of Wildlife and Fisheries official, provided the following details:

"Jerry Baker, 1022 Franklin Road, Lake Charles, found a group of around twenty birds, two of which were banded, near his home, on the morning of March $10 . \mathrm{He}$ picked up five of the dead birds, including the two with bands, and brought them to my office for identification. They seemed to 
have frozen to death during the sudden change in temperature during the night, from the mid-fifties $\mathrm{F}$ (about 13 C), to below freezing. This event followed a very mild winter."

Coupled with the Nebraska weather death (\#4 in Table 1), ${ }^{3}$ it provides evidence that swallow migration is both precarious and severely impacted by weather.

1. HARRIS, R. 2000. From the President. Bluebird 22(2):2.
2. STILES, D.J., and M.I. HOUSTON. 1994. Distant travels of Tree Swallows of the Prairie Provinces, 19681992. Blue Jay 52:206-212.

3. STILES, D.J. 1997. Recoveries of Mountain Bluebirds south of $49^{\circ}$ latitude, and a recent Tree Swallow. Blue Jay $55: 48-52$.

4. STILES, D.J. 1998. Interprovincial recoveries of Mountain Bluebirds and Tree Swallows, and a California recovery of a Tree Swallow. Blue Jay 56:156-159.

5. ROBERTSON, R.J., B.J. STUTCHBURY, and R.R. COHEN. Tree Swallow, In The Birds of North America, No. 11 (A. Poole, P. Stettenheim, and F. Gill, Eds.). Philadelphia: The Academy of Natural Sciences; Washington, DC: The American Ornithologists' Union.

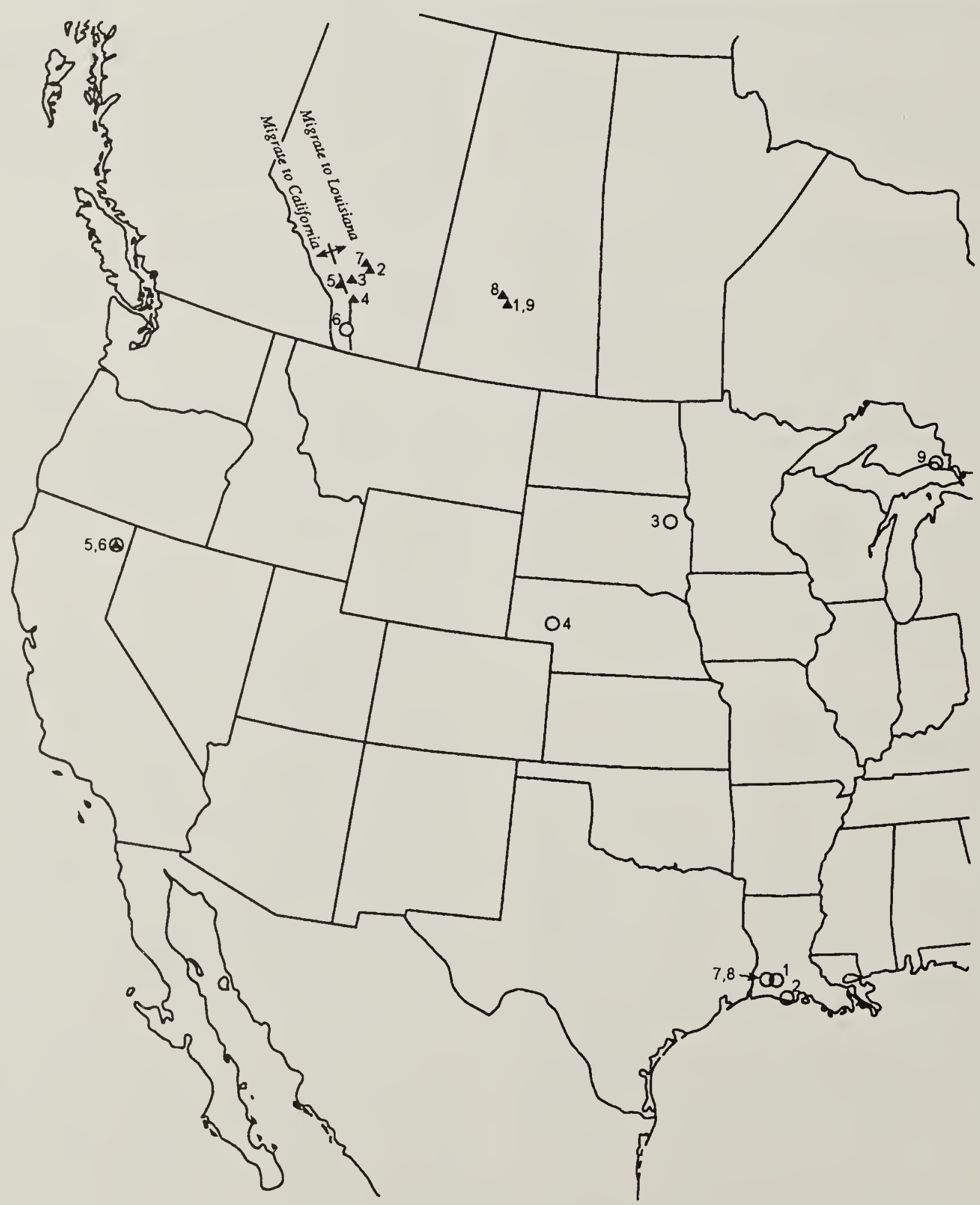

Fig. 1. Selected Tree Swallow Recoveries: triangles - banding locations, circles - recovery locations. 


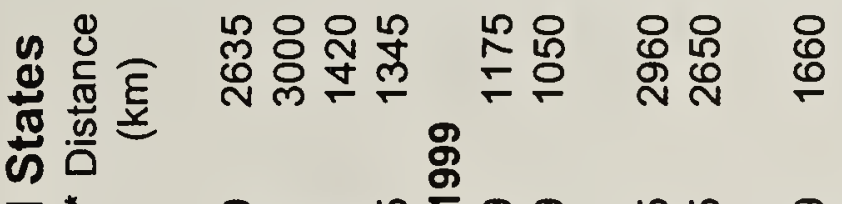

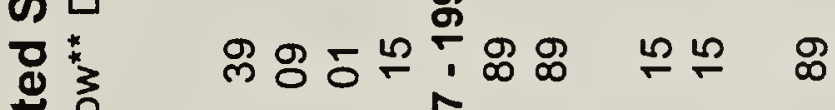

호도ำ

은

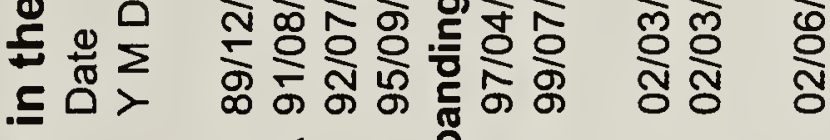

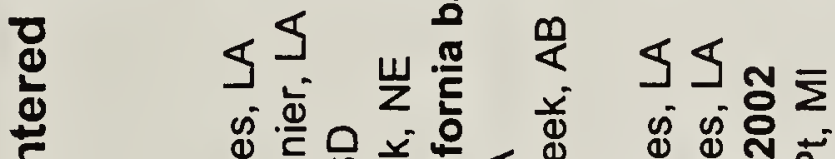

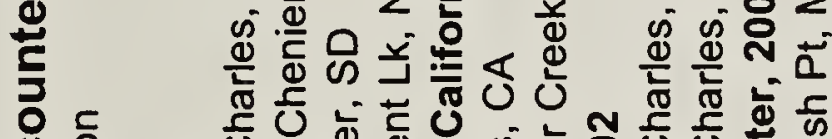

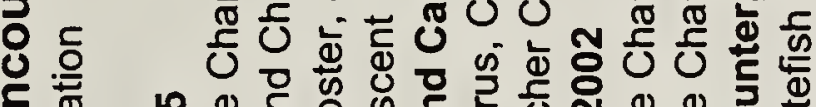

政

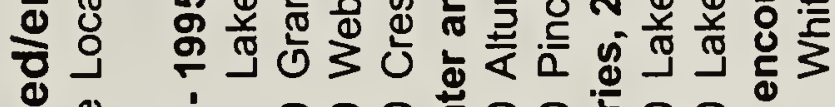

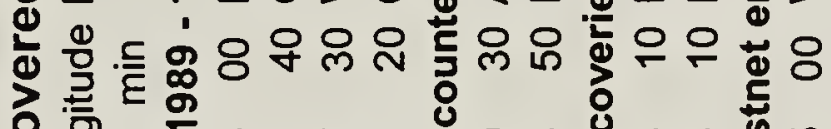

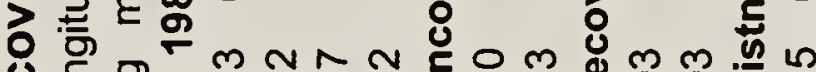

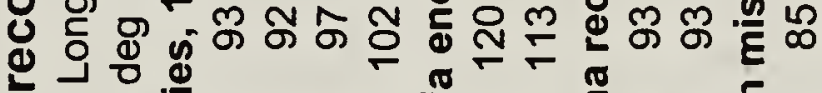

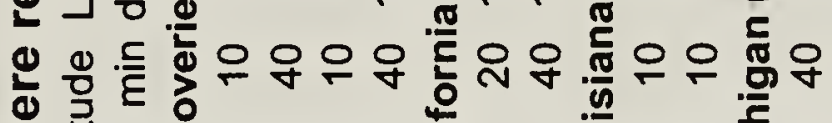

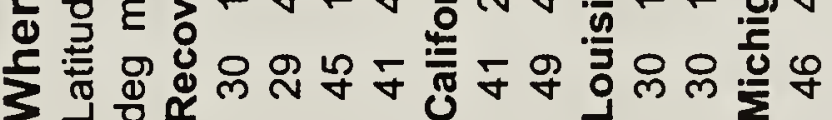

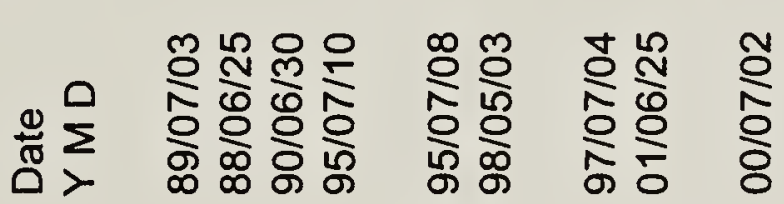

里

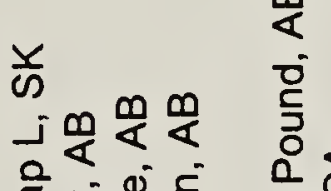

它产立

s

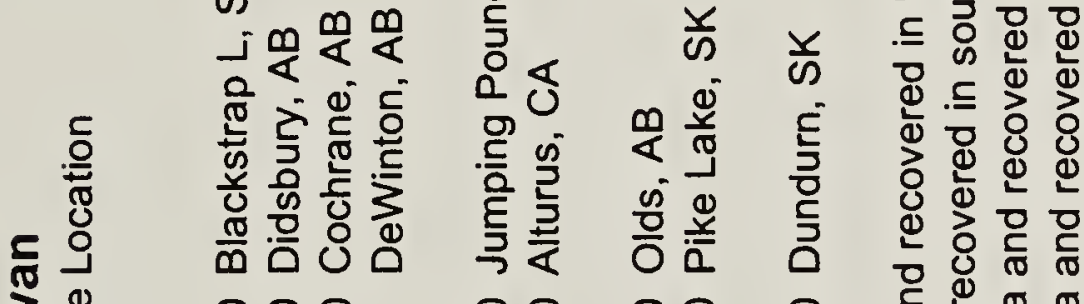

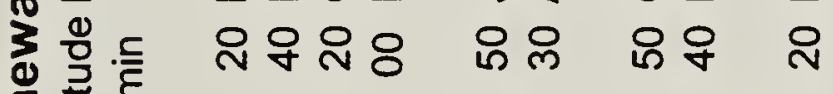

西

刃

U 융

\%

낭

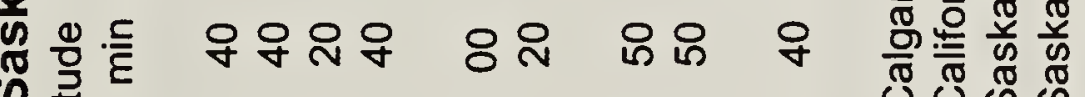

क率的地

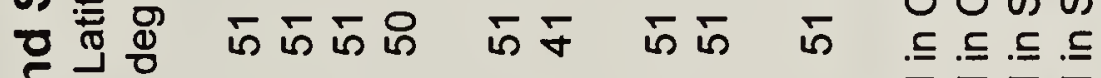

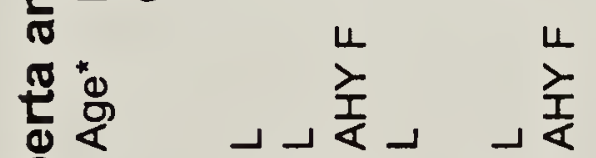

这

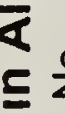

n)

ᄋ్

\lrcorner$\lrcorner\lrcorner$

8 80

응 용 赵

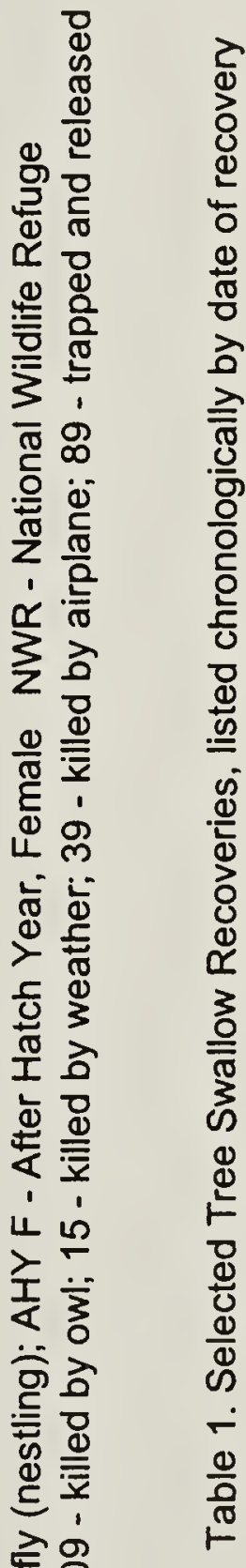

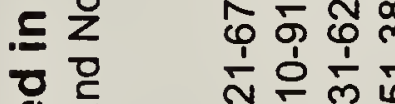

究

กับำ

ก

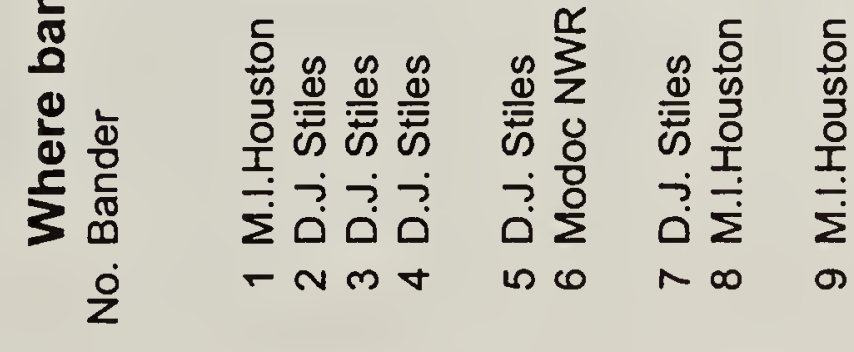

วั่

๘

요

음

(1)

in o तु

ن

त

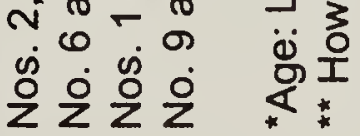

